\title{
A Comparison Of Surface Roughness Values of Various Restorative Materials Immersed in Pedodontic Pre- and Probiotics
}

\author{
Gunce Ozan $^{1 *}$ (D), Meltem Mert Eren ${ }^{2}$ iD , Aliye Tugce Gurcan ${ }^{3,}$, , Zuhal Yildirim Bilmez 4, (D), Yasemin \\ Yucel Yucel 5 (D)
}

1 Istanbul University Faculty of Dentistry, Dept. of Restorative Dentistry, Istanbul, Turkey; gunce.saygi@istanbul.edu.tr (G.O.);

2 Altinbas University Faculty of Dentistry, Dept. of Restorative Dentistry, Istanbul, Turkey; meltemmert@ hotmail.com (M.M.E.);

3 Altinbas University Faculty of Dentistry, Dept. of Pediatric Dentistry, Istanbul, Turkey; tugcetanyeri@gmail.com (A.T.G.);

4 Hatay Mustafa Kemal University Faculty of Dept. of Restorative Dentistry, Hatay, Turkey; zuhalyildirimbilmez@gmail.com (Z.Y.B.);

5 Altinbas University Faculty of Pharmacy, Dept. of Biochemistry, Istanbul, Turkey; yasemin.yucel@altinbas.edu.tr (Y.Y.Y.);

* Correspondence: gunce.saygi@ istanbul.edu.tr;

Scopus Author ID 57203243421

Received: 3.02.2021; Revised: 3.03.2021; Accepted: 5.03.2021; Published: 10.03.2021

Abstract: The present in vitro study aims to evaluate pre- and probiotic liquids' effect on surface roughness values of restorative materials after one month of immersion. 360 disc-shaped samples $(5 \mathrm{~mm}$ x $2 \mathrm{~mm}$ ) were prepared from two types of glass-ionomer cements (GIC), a resin-modified GIC, a compomer, three bulk-fill composites, and one microhybrid composite. After the surfaces were polished, samples were divided into three groups $(\mathrm{n}=15)$ and immersed for 10 minutes daily for one month in either a probiotic sachet, kefir (prebiotic), or artificial saliva. After that, the surface roughness values were measured by a profilometer. Scanning electron microscopy (SEM) evaluations of one sample from tested materials were also added. Statistical data were analyzed using one-way ANOVA and Bonferroni-Dunn tests. One of the GIC materials had significantly rougher surfaces in the probiotic sachet, followed by the compomer $(\mathrm{p}<0.05)$. The compomer showed the roughest surfaces after immersion in kefir, followed by the microhybrid composite (Z250). Probiotic sachets formed rougher surfaces than kefir among samples. SEM images revealed the inorganic filler structures and microcracks on the surfaces. A high-viscosity glass-ionomer cement, Equia Fil Forte, and other composite-based materials tested in the present study can be used in pediatric patients who use pre- and probiotic supplements.

Keywords: restorative materials; surface roughness; probiotics; kefir; scanning electron microscopy.

(C) 2021 by the authors. This article is an open-access article distributed under the terms and conditions of the Creative Commons Attribution (CC BY) license (https://creativecommons.org/licenses/by/4.0/).

\section{Introduction}

Improvements in the formula of the matrices and new filler structures influenced by nanotechnology have led to superior physical, mechanical, and esthetic properties of resinbased restorative materials [1]. Modifications of inorganic fillers of resin composites ensure better wear resistance, polishability, and lower surface roughness. Optimum surface smoothness is an important factor in maintaining surface quality. Moreover, a rougher surface 
may cause staining, discoloration, bacterial accumulation, secondary caries, and gingival inflammation [2,3]. To prevent these complications, materials should be finished and polished using ideal equipment and cautiously polymerized [4,5]. Furthermore, roughness values above $0.3 \mu \mathrm{m}$ are detectable by patients' tongues and cause discomfort, especially for pedodontic patients [6].

Not only are resin-based materials used in pedodontic patients, but also GICs are frequently used. Conventional GICs are proven to be viable restoration choices for primary molars, and resin-modified glass ionomers (RMGIC) are preferred since they are easy to handle and ideal for marginal adaptation [7]. Some studies determined that innovations of high-viscous glass-ionomer cements (HV-GICs) have the advantage of conventional GICs and enhanced mechanical and wear properties [8,9]. Although GIC showed promising clinical results as a permanent filling [10] and is essential as an added protection against caries in children, the release of fluoride ions from these materials cause further deterioration of the surface, resulting in high-surface roughness values and an accumulation of plaque [11].

Low and high viscosity bulk-fill composites have recently been developed for layering materials in a single application [12]. These materials have better marginal adaptation, lower technical sensitivity, and less bubble formation. Additionally, this timesaving application is a good option for pedodontic patients. Regarding surface roughness properties, there are conflicting results among studies that compare bulk-fill to conventional resin composites [1315]. However, studies investigating the effect of pre- and probiotic liquids on these restorative materials' surface properties are rare.

Probiotics are available for sale as dietary supplements composed of beneficial bacteria and yeast, which play a vital role in strengthening the immune system. Similarly, prebiotics improves health by stimulating the amount and activity of probiotics [16]. Supplements are important not only for general health but also for some of their essential oral health effects. Dairy probiotics were proven useful for reducing Streptococcus mutans (S. mutans) and increasing $\mathrm{pH}$ balance in saliva [17]. Moreover, pre- and probiotics contain many micronutrients, such as $\mathrm{Ca}^{+2}$ and $\mathrm{Mg}^{+2}$, that may provide the ionic balance of oral biofilm [18]. These supplements for children are usually contained in packets for children and consumed for months to provide a strong immune system. Because these products have low $\mathrm{pH}$ values and are being used regularly for a period, they may affect restorations. To our knowledge, studies to examine surface properties of these pre- and probiotics have not been conducted. Therefore, the present study evaluates the effects of pre- and probiotics consumed by children on various restorative materials' surface roughness values. Artificial saliva was included as the negative control, and the samples' surface topographies contributed to the study to support the profilometric findings. In contrast, SEM images were added to analyze the differences among surface features of the tested materials. The null hypotheses were: (1) there would be no significant difference between tested restorative materials, and (2) there would be no significant difference among the effect of tested liquids.

\section{Materials and Methods}

\subsection{Preparation of the specimens.}

A conventional GIC, an HV-GIC, an RMGIC, a compomer, three bulk-fill composites, and a microhybrid resin-based composite were tested in the present in vitro study. Compositions and types of the related materials are presented in Table 1. A total of 360 samples 
were fabricated using a cylindrical metallic mold ( $5 \mathrm{~mm}$ in diameter and $2 \mathrm{~mm}$ thick). Each material was inserted into the mold and confined between two opposing transparent matrix strips. A glass microscope slide (1 mm in thickness) was then placed over the mold, and constant pressure was applied to extrude the excess material. All the restorative materials were polymerized according to the manufacturers' recommended polymerization duration with a LED light-curing unit (Valo LED Curing Light; Ultradent Products Inc., UT, USA) operating in standard mode. The light-curing unit's tip was placed perpendicular to the specimen's surface at a distance of $1 \mathrm{~mm}$, and the power of the curing unit was measured with a radiometer before the beginning of each polymerization. Afterward, specimens were removed from the mold and kept in distilled water at $37^{\circ} \mathrm{C}$ on a stove for 24 hours for post-polymerization. Then, Sof-Lex discs (3M ESPE, St Paul, MN, USA) were used to finish and polish all specimens. To reduce variability, the same investigator performed finishing and polishing procedures, and the discs were renewed after their $3^{\text {rd }}$ use. Then specimens were kept in distilled water at $37^{\circ} \mathrm{C}$ until the experimental period.

Table 1. Brand, type, and composition of the tested materials used in the study.

\begin{tabular}{|c|c|c|c|c|}
\hline Name & Brand & $\begin{array}{l}\text { Lot } \\
\text { No. }\end{array}$ & Type & Composition \\
\hline $\begin{array}{l}\text { Ketac Molar } \\
\text { EasyMix } \\
(\mathrm{KM})\end{array}$ & $\begin{array}{l}3 \mathrm{M} \\
\text { Espe }\end{array}$ & $\begin{array}{l}6383 \\
514\end{array}$ & $\begin{array}{l}\text { Convention } \\
\text { al Glass } \\
\text { Ionomer } \\
\text { Cement } \\
\text { (GIC) }\end{array}$ & $\begin{array}{l}\text { Powder: Aluminium-calcium-lanthanum fluorosilicate glass } \\
\text { Liquid: polycarboxylic acid }\end{array}$ \\
\hline $\begin{array}{l}\text { Equia Forte } \\
\text { Fil (EFF) }\end{array}$ & $\mathrm{GC}$ & $\begin{array}{l}1805 \\
16 \mathrm{~A}\end{array}$ & $\begin{array}{l}\text { High } \\
\text { viscosity } \\
\text { glass } \\
\text { ionomer } \\
\text { (HV-GIC) }\end{array}$ & $\begin{array}{l}\text { Powder: Fluoroaluminasilicate glass, polyacrylic acid, iron oxide } \\
\text { Liquid: Polybasic carboxylic acid, water }\end{array}$ \\
\hline $\begin{array}{l}\text { Geristore } \\
(\mathrm{GS})\end{array}$ & $\begin{array}{l}\text { DenM } \\
\text { at }\end{array}$ & $\begin{array}{l}1907 \\
9000 \\
02\end{array}$ & $\begin{array}{l}\text { Resin } \\
\text { modified } \\
\text { glass } \\
\text { ionomer }\end{array}$ & $\begin{array}{l}\text { Aromatic dimethacrylate, HEMA, Barium-fluorosilicate glass, } \\
\text { silica, initiators, stabilizers }(3.5 \mu \mathrm{m})(50 \% \text { wt. })\end{array}$ \\
\hline $\begin{array}{l}\text { Dyract XP } \\
(\mathrm{DXP})\end{array}$ & $\begin{array}{l}\text { Dents } \\
\text { ply } \\
\text { Sirona }\end{array}$ & 0604 & Compomer & $\begin{array}{l}\text { TCB resin, UDMA, Strontium-fluoro-silicate glass, strontium } \\
\text { fluoride, photoinitiator, stabilizers }(0.8 \mu \mathrm{m}, 47 \% \mathrm{wt}, 50 \% \text { vol. } \\
\text { fillers })\end{array}$ \\
\hline $\begin{array}{l}\text { Beautiful- } \\
\text { Bulk (BB) }\end{array}$ & Shofu & $\begin{array}{l}0517 \\
27\end{array}$ & $\begin{array}{l}\text { Bulk-fill } \\
\text { composite }\end{array}$ & $\begin{array}{l}\text { Fluoro-alumino-silicate glass, BisGMA, UDMA, TEGDMA, } \\
\text { BisMPEPP, Reaction initiator, others ( } 75 \% \text { wt.) }\end{array}$ \\
\hline $\begin{array}{l}\text { Venus Bulk } \\
\text { Fill (VB) }\end{array}$ & Kulzer & $\begin{array}{l}\text { K01 } \\
0206\end{array}$ & $\begin{array}{l}\text { Bulk-fill } \\
\text { composite }\end{array}$ & $\begin{array}{l}\text { UDMA, EBPDMA, barium glass, ytterbium trifluoride, silicon } \\
\text { dioxide ( } 65 \% \text { wt, } 38 \% \text { vol.) }\end{array}$ \\
\hline $\begin{array}{l}\text { SonicFill } \\
\text { (SF) }\end{array}$ & Kerr & $\begin{array}{l}6599 \\
433\end{array}$ & $\begin{array}{l}\text { Bulk-fill } \\
\text { composite }\end{array}$ & TMSPMA, EBPADMA, TEGDMA, oxide, $\mathrm{SiO}_{2}(83.5 \%$ wt.) \\
\hline $\begin{array}{l}\text { Filtek Z250 } \\
(\mathrm{Z} 250)\end{array}$ & $\begin{array}{l}3 \mathrm{M} \\
\text { Espe }\end{array}$ & $\begin{array}{l}\text { N97 } \\
0668\end{array}$ & $\begin{array}{l}\text { Convention } \\
\text { al resin } \\
\text { composite }\end{array}$ & $\begin{array}{l}\text { Bis-GMA, Bis-EMA, UDMA, TEGDMA, zirconia, silica (0.01 - } \\
3.5 \mu \mathrm{m}),(78 \mathrm{wt} \%, 60 \mathrm{vol} \%)\end{array}$ \\
\hline
\end{tabular}

\subsection{Experimental period.}

Specimens from each group $(n=15)$ were stored for $10 \mathrm{~min} /$ day for one month in a cup of one of the following groups: Probiotic sachet, kefir, and artificial saliva as control. Manufacturers and the content of the beverages are given in Table 2. A probiotic sachet was mixed with $200 \mathrm{ml}$. of water to obtain a solution, and the $\mathrm{pH}$ value of each beverage was determined using a $\mathrm{pH}$ meter (Orion 420, Beverly, MA, USA). All of the beverages were used at room temperature and were renewed during every period. The specimens were kept 
immersed in distilled water at $37 \pm 1^{\circ} \mathrm{C}$ between cycles. Specimens were re-placed in cups in each cycle so that the experimental surfaces were completely in contact with the beverages.

Table 2. Brand, $\mathrm{pH}$, and composition of the groups.

\begin{tabular}{|c|c|c|c|c|}
\hline Groups & Name & Brand & $\mathbf{P h}$ & Composition \\
\hline $\begin{array}{l}\text { Probiotic } \\
\text { sachet }\end{array}$ & $\begin{array}{l}\text { Nutrigen } \\
\text { Inulin }\end{array}$ & $\begin{array}{l}\text { Nutrigen, } \\
\text { Istanbul, } \\
\text { Turkey }\end{array}$ & 3.0 & Inulin, polydextrose, vitamins, folic acid, $\mathrm{Se}, \mathrm{Cr}, \mathrm{Mg}$, I. \\
\hline $\begin{array}{l}\text { Kefir } \\
\text { (prebiotic) }\end{array}$ & $\begin{array}{l}\text { Pinar Cilekli } \\
\text { Kefir }\end{array}$ & $\begin{array}{l}\text { Pinar Inc., } \\
\text { Izmir, Turkey }\end{array}$ & 4.4 & Cow milk, yeast, kefir, milk fat, lactoprotein \\
\hline $\begin{array}{l}\text { Artificial } \\
\text { saliva } \\
\text { (Control) }\end{array}$ & & - & 7.0 & $\begin{array}{l}\text { Calcium hydroxide, } 0.9 \mathrm{mM} \text { of phosphorus and potassium ( } 0.1225 \mathrm{~g} \\
\text { potassium phosphate monobasic/L of deionized water), } 20 \mathrm{mM} \text { TRIS } \\
\text { buffer* }\end{array}$ \\
\hline
\end{tabular}

\subsection{Surface roughness measurements.}

The roughness values for each specimen were measured with three consecutive readings in the middle region of the specimens, and mean Ra values were calculated. Before the measurement, each specimen's top surface was blotted dry using tissue paper and a surface profilometer's contact guide (Taylor Hobson Surtronic+, Taylor Hobson Ltd, Leicester, UK) the center of the specimen surface. The profilometer, calibrated against a standard after each measurement, was set to a cutoff value of $0.25 \mathrm{~mm}$, a transverse length of $1.25 \mathrm{~mm}$, and a stylus speed of $0.1 \mathrm{~mm} / \mathrm{s}$. Measurements were taken directly after polishing the specimens (baseline) and one month.

\subsection{Surface topography examination.}

A specimen from each material's control group was examined under a triboindentor ( $\mathrm{Ti}$ 950, Hysitron, MN, USA) to compare the surface characteristics. A diamond Berkovich tip was used to scan an area of $40 \times 40 \mu \mathrm{m}$ from the middle of the specimens with an imaging force maintained at $0.5 \mu \mathrm{N}$. Maximum height levels of the surfaces were evaluated.

To compare tested materials' surface characteristics, a novel specimen with $5 \mathrm{~mm}$ in diameter and $2 \mathrm{~mm}$ thick had prepared for SEM examination from each material group. Specimens were fabricated by utilizing a cylindrical metallic mold, and after 24 hours, finishing and polishing procedures were applied with Sof-Lex discs. Then, all of the specimens were kept in artificial saliva for 48 hours. For SEM evaluation, specimens were sputter-coated with gold (Polaron SC7620, Quorum Technologies, UK) and were examined under an SEM (JEOL $5500 \mathrm{LV}$, JEOL, Japan) at $10 \mathrm{kV}$ accelerating voltage. Photographs of the representative areas of the polished surfaces were taken under $\times 1000$ magnification. All of the images were taken by the same operator.

\subsection{Statistical analysis.}

The statistical analysis was done using SPSS 24.0 (SPSS, Chicago, IL, USA) at a significance level of 0.05 . The results were primarily analyzed using the Kolmogorov-Smirnov test to determine the existence of a normal distribution. Since the data were normally distributed, differences observed within each material were analyzed by Student's $t$-test. Further statistical analyses for cross-comparing the test materials were performed by one-way ANOVA and Bonferroni/Dunn test. 


\section{Results and Discussion}

According to our results, a significant difference was not observed in the specimens of EFF and GS; however, other tested restorative materials showed significant differences after one month of immersion ( $\mathrm{p}<0.05$ ). Mean surface roughness values and standard deviations of tested materials are shown in Table 3. In the KM, SF, and Z250 specimens, all tested liquids showed significantly higher roughness values except for the KM specimens immersed in kefir. Specimens of VB, BB, and DXP had significantly rougher surfaces after one month of immersion in probiotics. Similarly, specimens of DXP showed significantly higher roughness values in kefir after one month $(\mathrm{p}<0.05)$. There were no other significant changes among groups after immersion in the specified duration of time.

Table 3. Mean and standard deviations of Ra values $(\mu \mathrm{m})$ of all tested materials immersed in probiotic beverages*.

\begin{tabular}{l|l|l|l|l|l|l} 
& \multicolumn{2}{|c|}{ Probiotic } & \multicolumn{2}{c|}{ Kefir } & \multicolumn{2}{c}{ Artificial saliva } \\
\hline Restorative materials & Baseline & $\mathbf{1}$ month & Baseline & $\mathbf{1}$ month & Baseline & $\mathbf{1}$ month \\
\hline $\begin{array}{l}\text { Ketac Molar EasyMix } \\
(\text { KM) }\end{array}$ & $0.97 \pm 0.26^{\mathrm{Aa}}$ & $1.12 \pm 0.32^{\mathrm{Ce}}$ & $0.91 \pm 0.22^{\mathrm{Aa}}$ & $0.56 \pm 0.21^{\mathrm{De}}$ & $0.55 \pm 0.10^{\mathrm{Bb}}$ & $0.70 \pm 0.23^{\mathrm{Dd}}$ \\
\hline Equia Forte Fil (EFF) & $0.50 \pm 0.15^{\mathrm{Ab}}$ & $0.50 \pm 0.20^{\mathrm{Cg}}$ & $0.41 \pm 0.12^{\mathrm{Ac}}$ & $0.38 \pm 0.19^{\mathrm{CDf}}$ & $0.28 \pm 0.07^{\mathrm{Ba}}$ & $0.28 \pm 0.05^{\mathrm{De}}$ \\
\hline Geristore (GS) & $0.81 \pm 0.26^{\mathrm{Ac}}$ & $\begin{array}{l}0.72 \pm \\
0.29^{\mathrm{CDf}}\end{array}$ & $0.44 \pm 0.06^{\mathrm{Bc}}$ & $0.44 \pm 0.10^{\mathrm{Cfe}}$ & $0.55 \pm 0.23^{\mathrm{Bb}}$ & $0.86 \pm 0.44^{\mathrm{Dc}}$ \\
\hline Dyract XP (DXP) & $0.34 \pm 0.08^{\mathrm{Ad}}$ & $0.87 \pm 0.16^{\mathrm{Bf}}$ & $0.36 \pm 0.07^{\mathrm{Abc}}$ & $0.75 \pm 0.10^{\mathrm{Cd}}$ & $0.42 \pm 0.15^{\mathrm{Aab}}$ & $0.40 \pm 0.05^{\mathrm{De}}$ \\
\hline Beautifil-Bulk (BB) & $0.42 \pm 0.11^{\mathrm{Ad}}$ & $0.50 \pm 0.12^{\mathrm{Bg}}$ & $0.41 \pm 0.11^{\mathrm{Ac}}$ & $0.39 \pm 0.16^{\mathrm{Cf}}$ & $0.39 \pm 0.07^{\mathrm{Aa}}$ & $0.41 \pm$ \\
& & & & & & $0.06^{\mathrm{BCe}}$ \\
\hline Venus Bulk Fill (VB) & $0.27 \pm 0.05^{\mathrm{Ad}}$ & $0.35 \pm 0.11^{\mathrm{Cg}}$ & $0.24 \pm 0.08^{\mathrm{Ab}}$ & $0.33 \pm 0.12^{\mathrm{Cf}}$ & $0.35 \pm 0.05^{\mathrm{Ba}}$ & $0.37 \pm 0.14^{\mathrm{Ce}}$ \\
\hline SonicFill (SF) & $0.36 \pm 0.12^{\mathrm{Ad}}$ & $0.65 \pm 0.19^{\mathrm{Bf}}$ & $0.35 \pm 0.06^{\mathrm{Abc}}$ & $0.54 \pm$ & $0.38 \pm 0.11^{\mathrm{Aa}}$ & $0.48 \pm$ \\
& & & & $0.09^{\mathrm{BCfe}}$ & & $0.10^{\mathrm{Cde}}$ \\
\hline Filtek Z250 (Z250) & $0.28 \pm 0.10^{\mathrm{Ad}}$ & $0.57 \pm$ & $0.25 \pm 0.09^{\mathrm{Ab}}$ & $0.61 \pm 0.17^{\mathrm{Bde}}$ & $0.32 \pm 0.15^{\mathrm{Aa}}$ & $\begin{array}{l}0.54 \pm \\
0.07^{\mathrm{Bde}}\end{array}$
\end{tabular}

* According to Bonferroni/Dunn tests, different uppercase letters show significant difference among base and 1-month scores of beverages in lines, and different lowercase letters show significant difference among the base and 1-month scores of materials in columns $(\mathrm{p}<0.05)$.

Statistical significance was found among tested liquids and the control group $(\mathrm{p}<0.05)$. When comparing the effect of pre- and probiotic liquids (excluding the specimens of GS), smoother surfaces were observed in the control group $(\mathrm{p}<0.05)$. There was no significant difference between the tested liquids and the control groups of VB and Z250 ( $p>0.05$ ). In the BB, DXP, and KM groups, kefir specimens showed significantly lower surface roughness values than probiotics. Furthermore, except for the GS and VB groups, the probiotic had the highest surface roughness values.

According to Bonferroni-Dunn tests, there is a significant difference between all groups $(\mathrm{p}<0.000)$. After one month of immersion, VB showed the smoothest surfaces in preand probiotic liquids. Specimens of EFF had the lowest roughness score in the control group. DXP showed superior results when immersed in artificial saliva; however, poor results were observed when it was immersed in pre- and probiotics. Significantly, the KM specimens had the roughest surfaces after immersion in probiotics $(\mathrm{p}<0.05)$. Geristore showed the roughest surfaces with significant differences in artificial saliva, followed by KM and Z250, respectively. 


\subsection{Nanoindentation and SEM images.}

The topographic images of each material taken from the triboIndentor are presented in Figure 1.



Figure 1. 3D topographic images of tested restorative materials. Representative images are shown for groups (a) $\mathrm{KM}$; (b) EFF; (c) GS; (d) DXP; (e) BB; (f) VB; (g) SF; (h) Z250. 

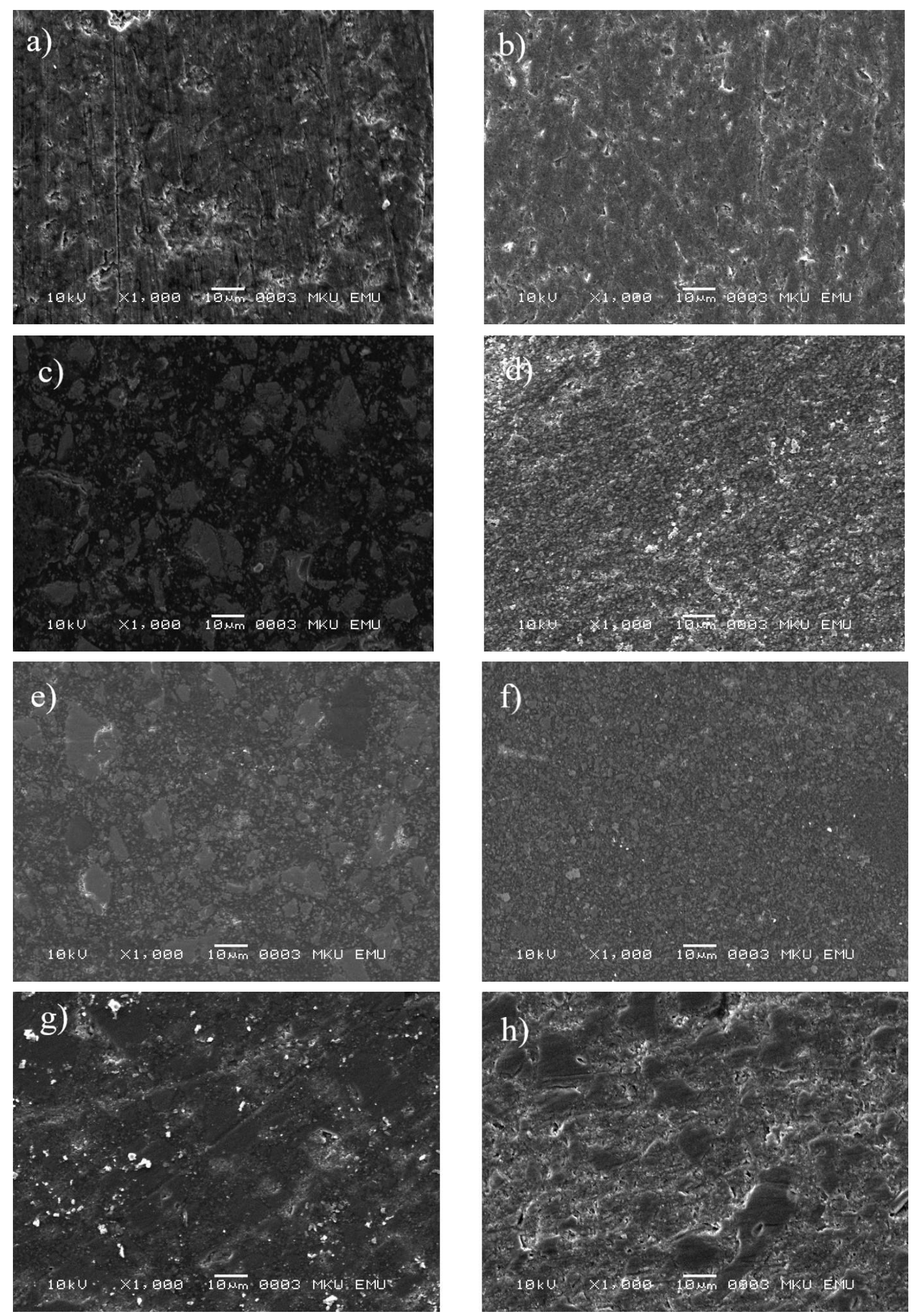

Figure 2. Scanning electron micrographs of the surfaces of the tested restorative materials at $\times 1000$ magnification. Images represent (a) KM; (b) EFF; (c) GS; (d) DXP; (e) BB; (f) VB; (g) SF; (h) Z250.

Evaluation of the images' features shows that the DXP group had the most surface elevations, showing the maximum height $(8.41 \mu \mathrm{m})$ among all groups (Figure $1 \mathrm{~d})$. In addition, extensive irregularities were also seen in the Z250 group, which had the maximum height of 
$8.24 \mu \mathrm{m}$, followed by the GS group $(8.08 \mu \mathrm{m})$. Bulk-fill groups showed similar surface properties, but these restorative materials had rougher surfaces compared to the KM and EFF groups. Among bulk-fill composites, the BB group showed a shorter elevation $(7.49 \mu \mathrm{m})$ than the surfaces of the VB and SF groups $(8.07 \mu \mathrm{m})$. According to nanoindentation images, $\mathrm{KM}$ $(7.11 \mu \mathrm{m})$ and EFF $(7.44 \mu \mathrm{m})$ had lower irregularity levels. SEM images of the tested materials' surfaces are shown in Figure 2.

Voids from finishing and polishing procedures are highly obvious in the KM and SF groups (Figures $2 \mathrm{a}$ and $2 \mathrm{~g}$ ). There are partial loss and holes throughout the surface of the EFF group (Figure 2b). Particles of irregular shapes and sizes are prominent in both the GS and BB groups also (Figures $2 \mathrm{c}$ and $2 \mathrm{e}$ ). A homogenous surface structure and small fillers are monitored in the VB group (Figure 2f). Microcracks and protruding particles are seen on the surface of the Z250 group (Figure $2 \mathrm{~h}$ ).

\subsection{Discussion.}

A healthy lifestyle has emerged as a global trend. Understanding the importance of beneficial gut bacteria has led people to use extra supplements comprised of dairy products. These bacteria also play a role in the oral cavity to reduce cariogenic bacteria's effects on teeth and restorative materials over time. The present study demonstrates that using pro- and prebiotics for one month had significantly altered many of the tested restorative materials' surfaces. Only EFF and GS specimens had no significant difference over time. Thus, the effect of tested liquids could vary among restorative materials.

Studies evaluating exogenous effects on materials have used different methodologies, especially among immersion times. Many of the studies have used uninterrupted immersion in liquids. Besides, the present study was designed to limit the duration of liquids in the oral cavity to 10 minutes, similar to the recent methodology of Gupta et al. [20]. Hence, this time duration is presumed to reflect the effects of tested liquids representing realistic conditions of restorative materials in the oral cavity. The surface roughness of dental restoratives was assessed using both qualitative and quantitative methods, including either 2D (mechanical) or 3D analysis (optical). The Contact profilometer was the most common mechanical method utilized because of its easy handling and repeated analyses [3]. The scanning electron microscope (SEM) is a 3D method that is frequently used in in vitro studies [21-23], but it does not allow specimens to be measured again; therefore, it is a nonrepetitive method. Thus, this current study used SEM images taken from new specimens and prepared specifically for this method. In contrast, atomic force microscopy (AFM), or nanoindentation devices, visualize the surface topography of restorative materials at a high resolution and do not harm the specimens' surface [24-27]. Based on gaining more valid predictions of surface roughness of various restorative materials, the present methodology was designed based on the average profilometer results and supported by the 3D images gained by nanoindentation. The maximum height of the surface elevations in 3D images was also evaluated; however, the nanoindentation and profilometer results did not fully support each other. The conflicting results of the two methods on some of the tested materials could be attributed to the limited section area of the nanoimages.

Various types of restorative materials (conventional glass ionomers, resin modifies glass ionomers, compomers, bulk-fills, and conventional composites) that could be used in pedodontic patients were included in the current study. Surface roughness values of materials were significantly different after immersion in tested liquids; thus, the first hypothesis was that there would be no significant difference between tested restorative materials - is rejected. The 
GS and KM groups showed significantly lower results among other groups. The KM, as a conventional glass ionomer, may have higher roughness scores than other resin-based materials because of their higher polishability capacity [28]. GS had higher roughness scores when immersed in artificial saliva after showing the same roughness values in tested pre- and probiotics (control). Additionally, nanoimages of the GS specimen, which was also taken from control group, showed irregular elevations indicating rougher surface texture (see Figure 1c). This could be attributed by its hydrophilic nature as a self-adhesive material. With the presence of acidic monomer in their structure, self-adhesives need water for ionization to bond with dental tissues [29]. Resin-based matrices of these materials are generally composed of hydrophilic monomers, such as HEMA in GS. Thus, absorption of water in the structure could result in higher surface roughness values in the study.

Restorations with higher surface roughness values are more prone to bacterial adhesion, deterioration, and discoloration, so that these hazardous situations may lower the longevity of the restorations [30]. Glass ionomers have been widely used, especially in pediatric dentistry, due to some advantages such as releasing fluoride, chemical bonding to dental hard tissues and easy-handling. Surface analysis of KM and an improved glass ionomer EFF were performed, and similar to the study by Milicevic et al. [31], the KM showed significantly higher roughness values. This could be caused by the low resistance of KM to acidic media. Both pre- and probiotic liquids have lower $\mathrm{pH}$ levels, which may have affected the conventional GIC. In lower $\mathrm{pH}$ levels, glass fillers of GIC materials became more sensitive and tended to break off, resulting in the decomposition of the matrices [32] and deterioration of polyacrylate salts [33]. Weak acid resistance could be responsible for the rougher surface levels of KM and the high viscosity EFF both at baseline and after one month. The EFF showed significantly lower roughness than $\mathrm{KM}$, and after one month of immersion, there were no significant differences between the roughness values of EFF and bulk-fill composites (VB, BB, and SF) in kefir and artificial saliva groups. Likewise, in bulk-fill groups, EFF showed significantly similar roughness scores with Z250 after immersion in probiotic and artificial saliva groups. The smaller and more reactive silicate glass [34] of EFF could be responsible for the specimens' composite-like roughness values. DXP is a compomer that is easily termed as a combination of the properties of glass ionomer and composites [35]. DXP, like glass GICs, contains fluorosilicate glass with strontium fillers settled in a resin-based matrix. Similar to the studies of Karda et al. [36] and Topaloglu-Ak et al. [37], DXP performed better than the GIC-based material but worse than composite materials regarding profilometric roughness scores. These scores could be related to DXP's average particle sizes $(0.8 \mu \mathrm{m})$, which are as small as composite materials. The dense structure of small particles is easily seen in the SEM image (Figure 2d).

The surface roughness of resin composites is affected by the type, shape, size, and distribution of the materials' inorganic fillers [30]. Depending on the experimental design's immersion period, the solubility and water-resistance of the resin-based matrices should impact tested materials. Regarding filler sizes, smaller fillers form smaller gaps, or voids, after finishing and polishing procedures $[15,38]$. Furthermore, small fillers with higher loading minimalize the spacing, which provides resistance to the resin matrix [30]. Therefore, the SF group, which has the smallest particle size with the highest loading, was expected to show the smoothest surfaces; however, it had numerically higher roughness scores among other bulk-fill composites. These low results of the current study are in accordance with the research by Karadas and Demirbuga [14] that found SF to be the second-roughest composite among the 
nano-fill and three bulk-fill composites. SF is a bulk-fill composite activated with a sonic system to fill cavities. The loosened bonding could explain these substandard results between the fillers and the material's resin matrix, releasing the rigid barium fillers after finishing and polishing procedures. Like the current study, there were obvious defects on SFs surfaces in a study supported by SEM [14].

In literature, there are conflicting results among the surface roughness scores of bulkfill and microhybrid composites. While Magdy et al. [15] had determined similar surface roughness values among bulk-fill and nanohybrid composites, some studies showed higher roughness scores in bulk-fill composites than nano- and microhybrid composites $[13,14]$. One reason could be that filler sizes do not vary widely in bulk-fill and conventional composites. For example, in the current study, the VB and Z250 composites had similar filler sizes but could not be compared because of BBs fillers' limited data. The current study found that Z250 had a numerically higher value than VB and BB in all groups. Moreover, after immersion in kefir, significantly rougher surfaces than VB and BB were shown again. Contrary to the study by Ruivo et al. [3], which had declared that resin-based materials with spherical or rhomboid filler structure (such as silica and zirconia) were able to have smoother surfaces, Z250 showed inferior surface characteristics with the related filler structure. The high filler loading of Z250 (78\%) or the effects of tested pro- and prebiotics' acidic nature may be responsible for these scores. Although the statistics do not show a significant difference among surface roughness values, when comparing VB and BB, VB showed smoother surfaces, which could be attributed to its higher polishability. In SEM images, a uniform particle distribution of the VB group appeared to have a homogenous surface (Figure 2f). Furthermore, the BB, a giomer containing silicate glass as its main component, is more sensitive against acidic $\mathrm{pH}$ levels than $\mathrm{Ba}$ or $\mathrm{Zr}$ fillers.

In evaluating the tested solutions, the current study declares that, except for VB and Z250, each material's one-month roughness scores were significantly different in tested materials. The KM, DXP, and BB groups had the roughest surfaces when immersed in the probiotic solution. Although the probiotic solution caused the roughest surfaces in the EFF and SF groups, the different scores in specimens immersed in kefir were not significant. Moreover, specimens of GS had the roughest surfaces in artificial saliva, of which the scores were significantly higher than the ones in kefir. Thus, the second hypothesis of the present studythat there would be no significant difference among the effect of tested liquids - is partially rejected. According to the present results, probiotic packets and kefir have acidic $\mathrm{pH}$ levels (3 and 4.4, respectively). It has been proven that restorative materials can degrade over time and show surface roughness, a reduction in wear, resistance, and microhardness under regular acidic conditions. In resin-based materials, mechanical and physical properties may be affected by accelerating biodegradation after collapsing the polymer matrix [39]. This may lead to residual monomers' release, the removal of fillers, the formation of holes and voids among the surface, an increase in surface roughness and topography, an increased risk of secondary caries, and pulpitis and debonding of the restorative material $[30,39,40]$. Among the tested liquids, it is plausible that probiotic packets with the lowest $\mathrm{pH}$ levels affected the surfaces more than the tested prebiotic, kefir.

In contrast, water absorption of the restorative materials directly influences the longevity of the restorations. Water is an integral part of GIC and GIC-based restorative materials because it is essential for both setting and proceeding the chain reaction in these materials [41]. However, gaining too much water results in expanding the material and 
decreasing its physical properties [42]. After the one-month immersion in artificial saliva, KM had the highest surface roughness among all materials; however, EFF as an RMGIC showed no difference in the current study. This could be attributed to the RMGIC's structural differences in polymerization processes. The light-curing and strong structure of EFF may result in lower water uptake and higher surface smoothness. Composite restorations may also be affected by aqueous environments about their resin content. The chemistry and structure of polymer matrices are the most important aspects in determining the sorption and solubility of dental composites [43]. The most widely used monomers of dental resins are bisphenol A glycol dimethacrylate (BISGMA), urethane dimethacrylate (UDMA), triethylene glycol dimethacrylate (TEGDMA), and bisphenol A ethoxylateddimethacrylate (BISEMA). TEGDMA and BISGMA are acknowledged as hydrophilic, and UDMA and BISEMA are relatively hydrophobic. BISEMA has fewer carbon-carbon double bonds that lead to a softer, less cross-linked organic matrix than UDMA [30]. More hydrophilic monomers absorb more water; thus, resin-based matrices begin to soften and result in the displacement of filler particles, increased surface roughness, and reduced surface microhardness [42]. Furthermore, due to hydrolysis of the silane interface and the loss of chemical bonds between filler particles, the material's degradation ultimately occurs [44]. In the present study design, specimens were immersed in liquids for 10 minutes for 30 days; consequently, the resin-based matrices should be affected by water uptake from tested liquids and artificial saliva. It is plausible that the GS had the highest roughness scores in artificial saliva because of its HEMA content. Among the Z250 and bulk-fill composite materials, there were no significant differences after the onemonth immersion in artificial saliva, but Z250 had the highest numerical roughness score. This result is according to studies by Gonulol et al. [45] and Haugen et al. [46] in which conventional composites were determined not to have superior results over bulk-fill composites with regard to surface roughness. The substandard results of the Z250 specimens may be attributed to its unsilanated fillers that weaken the filler-matrix interface [45]. The outcome is that fillers may pull out of the resin matrix after the water uptake.

As the present study is an in vitro research, there were limitations, which were delineated. Firstly, while consuming pre- and probiotic liquids, the saliva's flow and buffering capacity are affected. However, artificial saliva was used only as a control group; therefore, liquids' acidity on the restorative material surfaces may be lower than the in vitro results. Secondly, the biofilm formed on the restorative materials may protect the restorations from the acidic and hygroscopic effect of liquids; thus, the current in vitro study could not benefit from the main elements of the oral cavity. Thirdly, because this study investigated several restorative materials, nanoimages were taken only from the control group. The surface changes regarding the effects of liquids should be evaluated with images in further studies. Lastly, the results refer to a one-month consumption of the liquids, which were also used as supplements, so long-term results (such as three to six months) could also be investigated.

\section{Conclusions}

Within this study's limitations, a conventional glass-ionomer cement, Ketac Molar, and a self-adhesive resin-modified glass ionomer, Geristore, were explored as being more susceptible to acidic pre- and probiotics. A high viscosity glass ionomer, Equia Fil Forte, and other composite-based materials were tested in the present study and can be used in pediatric patients consuming pre- and probiotic supplements. Thus, the present study reveals suitable material options for patients using the related supplements. Moreover, patients should 
periodically visit the pediatric dentist to monitor their existing restorations because of these liquids' acidic nature. Long-term clinical investigation of these materials with different preand probiotic supplements is needed to support the current study's findings.

\section{Funding}

This research received no external funding.

\section{Acknowledgments}

None.

\section{Conflicts of Interest}

The authors declare no conflict of interest.

\section{References}

1. da Silva, T. M.; Dantas, D. C. B.; Franco, T. T.; Franco, L. T.; Huhtala, M. F. R. L. Surface degradation of composite resins under staining and brushing challenges. J. Dent. Sci. 2019, 14(1), 87-92, https://doi.org/10.1016/j.jds.2018.11.005.

2. Lai, G.; Zhao, L.; Wang, J.; Kunzelmann, K.-H. Surface properties and color stability of dental flowable composites influenced by simulated toothbrushing. Dent. Mater. J. 2018, 37, 717724, https://doi.org/10.4012/dmj.2017-233.

3. Ruivo, M.A.; Pacheco, R.R.; Sebold, M.; Giannini, M. Surface roughness and filler particles characterization of resin-based composites. Microsc. Res. Tech. 2019, 82, 1756-1767, https://doi.org/10.1002/jemt.23342.

4. Rizzante, F. A.; Bombonatti, J. S.; Vasconcelos, L.; Porto, T. S.; Teich, S.; Mondelli, R. F. Influence of resin-coating agents on the roughness and color of composite resins. J. Prosthet. Dent. 2019, 122(3), 332e1, https://doi.org/10.1016/j.prosdent.2019.05.011.

5. St-Pierre, L.; Martel, C.; Crépeau, H.; Vargas, M. A. Influence of polishing systems on surface roughness of composite resins: polishability of composite resins. Oper. Dent. 2019, 44(3), E122-E132, https://doi.org/10.2341/17-140-L.

6. Erdemir, U.; Sancakli, H.S.; Yildiz, E. The effect of one-step and multi-step polishing systems on the surface roughness and microhardness of novel resin composites. European journal of dentistry 2012, 6, 198, https://doi.org/10.1055/s-0039-1698951.

7. Francois, P.; Vennat, E.; Le Goff, S.; Ruscassier, N.; Attal, J.-P.; Dursun, E. Shear bond strength and interface analysis between a resin composite and a recent high-viscous glass ionomer cement bonded with various adhesive systems. Clin. Oral Investig. 2019, 23, 2599-2608, https://doi.org/10.1007/s00784-0182678-5.

8. Yap, A.U.; Ong, J.E.; Yahya, N.A. Effect of resin coating on highly viscous glass ionomer cements: A dynamic analysis. J. Mech. Behav. Biomed. Mater. 2021, 113, 104120, https://doi.org/10.1016/j.jmbbm.2020.104120.

9. Lazaridou, D.; Belli, R.; Krämer, N.; Petschelt, A.; Lohbauer, U. Dental materials for primary dentition: are they suitable for occlusal restorations? A two-body wear study. Eur. Arch. Paediatr. Dent. 2015, 16, 165172, https://doi.org/10.1007/s40368-014-0151-y.

10. Poggio, C.; Dagna, A.; Chiesa, M.; Colombo, M.; Scribante, A. Surface roughness of flowable resin composites eroded by acidic and alcoholic drinks. Journal of conservative dentistry: JCD 2012, 15, 137, https://doi.org/10.4103/0972-0707.94581.

11. Fúcio, S.B.P.; Paula, A.B.d.; Sardi, J.C.O.; Duque, C.; Correr-Sobrinho, L.; Puppin-Rontani, R.M. Streptococcus mutans biofilm influences on the antimicrobial properties of glass ionomer cements. Braz. Dent. J. 2016, 27, 681-687, http://dx.doi.org/10.1590/0103-6440201600655.

12. Walter, R. Bulk-Fill Flowable Composite Resins. Journal of Esthetic and Restorative Dentistry 2013, 25 , 72-76, https://doi.org/10.1111/jerd.12011. 
13. O'Neill, C.; Kreplak, L.; Rueggeberg, F.A.; Labrie, D.; Shimokawa, C.A.K.; Price, R.B. Effect of tooth brushing on gloss retention and surface roughness of five bulk-fill resin composites. Journal of Esthetic and Restorative Dentistry 2018, 30, 59-69, https://doi.org/10.1111/jerd.12350.

14. Karadaş, M.; Demirbuğa, S. Evaluation of color stability and surface roughness of bulk-fill resin composites and nanocomposites. Meandros Medical and Dental Journal 2017, 18, 199, https://doi.org/10.4274/meandros.36855.

15. Magdy, N.M.; Kola, M.Z.; Alqahtani, H.H.; Alqahtani, M.D.; Alghmlas, A.S. Evaluation of Surface Roughness of Different Direct Resin-based Composites. J Int Soc Prev Community Dent 2017, 7, 104-109, https://doi.org/10.4103/jispcd.JISPCD_72_17.

16. Manigandan, T.; Mangaiyarkarasi, S.P.; Hemalatha, R.; Hemalatha, V.T.; Murali, N.P. Probiotics, prebiotics and synbiotics-a review. Biomedical \& Pharmacology Journal 2012, 5, 295, https://doi.org/10.13005/bpj/357.

17. Nadelman, P.; Magno, M.B.; Masterson, D.; da Cruz, A.G.; Maia, L.C. Are dairy products containing probiotics beneficial for oral health? A systematic review and meta-analysis. Clin. Oral Investig. 2018, 22, 2763-2785, https://doi.org/10.1007/s00784-018-2682-9.

18. Kumar, S.D.; Narayan, G.; Hassarajani, S. Determination of anionic minerals in black and kombucha tea using ion chromatography. Food Chem. 2008, 111, 784-788, https://doi.org/10.1016/j.foodchem.2008.05.012.

19. Ozera, E.H.; Pascon, F.M.; Correr, A.B.; Puppin-Rontani, R.M.; Castilho, A.R.d.; Correr-Sobrinho, L.; Paula, A.B.d. Color stability and gloss of esthetic restorative materials after chemical challenges. Braz. Dent. J. 2019, 30, 52-57, https://doi.org/10.1590/0103-6440201902263.

20. Gupta, R.; Madan, M.; Dua, P.; Saini, S.; Mangla, R.; Kainthla, T.; Dupper, A. Comparative Evaluation of Microhardness by Common Drinks on Esthetic Restorative Materials and Enamel: An in vitro Study. International journal of clinical pediatric dentistry 2018, 11, 155, https://doi.org/10.5005/jp-journals-100051503.

21. Ishii, R.; Takamizawa, T.; Tsujimoto, A.; Suzuki, S.; Imai, A.; Barkmeier, W. W.; Latta, M.A.; Miyazaki, M. Effects of finishing and polishing methods on the surface roughness and surface free energy of bulk-fill resin composites. Oper. Dent. 2020, 45(2), E91-E104, https://doi.org/10.2341/18-246-L.

22. Wheeler, J.; Deb, S.; Millar, B. J. Evaluation of the effects of polishing systems on surface roughness and morphology of dental composite resin. Brit. Dent J. 2020, 228(7), 527-532, https://doi.org/10.1038/s41415020-1370-8.

23. Ozduman, Z. C.; Kazak, M.; Fildisi, M. A.; Ozlen, R. H.; Dalkilic, E.; Donmez, N. Effect of polymerization time and home bleaching agent on the microhardness and surface roughness of bulk-fill composites: a scanning electron microscopy study. Scanning. 2019, 2019, 1-8, https://doi.org/10.1155/2019/2307305.

24. Karatas, O.; Gul, P.; Gündoğdu, M.; Iskenderoglu, D.T. An evaluation of surface roughness after staining of different composite resins using atomic force microscopy and a profilometer. Microsc. Res. Tech. 2020, 83, 1251-1259, https://doi.org/10.1002/jemt.23519.

25. Incesu, E.; Yanikoglu, N. Evaluation of the effect of different polishing systems on the surface roughness of dental ceramics. J. Prosthet. Dent. 2020, 124(1), 100-109, https://doi.org/10.1016/j.prosdent.2019.07.003.

26. Crăciun, A.; Bâldea, I.; Ispas, A.; Badea, M. E.; Petean, I.; Sarosi, C.; Moldovan, M.; Cuc, Stanca.; Ene, Razvan; Crişan, M. Evaluation of Surface Characteristics and Cytotoxicity of Dental Composites. Coatings, 2020, 10(8), 749., https://doi.org/10.3390/coatings10080749.

27. Soliman, Y. A.; Mahmoud, E. M.; Gepreel, M. A.; Afifi, R. R. Surface Roughness of Nanohybrid Composites with Different Monomers after Finishing and Polishing with Different Polishing Systems. Key Engineering Materials, 2020, 835, 41-49, https://doi.org/10.4028/www.scientific.net/KEM.835.41.

28. Abhyankar, V.; Hansen, J. Successful management of extensive root caries with gingival recession using a multidisciplinary team approach-A case report of a 1-year follow-up. Int J Med Dent Case Rep 2018, 5, 14, https://doi.org/10.15713/ins.ijmdcr.98.

29. Madruga, F.C.; Ogliari, F.A.; Ramos, T.S.; Bueno, M.; Moraes, R.R. Calcium hydroxide, pH-neutralization and formulation of model self-adhesive resin cements. Dent. Mater. 2013, 29, 413-418, https://doi.org/10.1016/j.dental.2013.01.004.

30. Ozan, G.; Eren, M.M.; Yildiz, S.O.; Sancakli, H.S.; Yildiz, E. Effects of acidic/alcoholic beverages on the surface roughness of composite resins light-cured for two different periods of time. Stoma Edu J, 2019, 6(4): 221-229, https://doi.org/10.25241/stomaeduj.2019.6(4).art.1. 
31. Miličević, A.; Goršeta, K.; van Duinen, R.N.V.; Glavina, D. Surface Roughness of Glass Ionomer Cements after Application of Different Polishing Techniques. Acta Stomatol. Croat. 2018, 52, 314-321, https://doi.org/10.15644/asc52/4/5.

32. Al-Samadani, K.H. Influence of energy beverages on the surface texture of glass lonomer restorative materials. J. Contemp. Dent. Pract. 2017, 18, 937-942, https://doi.org/10.5005/jp-journals-10024-2153.

33. Guler, S.; Unal, M. The Evaluation of Color and Surface Roughness Changes in Resin based Restorative Materials with Different Contents After Waiting in Various Liquids: An SEM and AFM study. Microsc. Res. Tech. 2018, 81, 1422-1433, https://doi.org/10.1002/jemt.23104.

34. Koc Vural, U.; Meral, E.; Ergin, E.; Gürgan, S. Twenty-four-month clinical performance of a glass hybrid restorative in non-carious cervical lesions of patients with bruxism: a split-mouth, randomized clinical trial. Clin. Oral Investig. 2020, 24, 1229-1238, https://doi.org/10.1007/s00784-019-02986-x.

35. Bayrak, G.D.; Sandalli, N.; Selvi-Kuvvetli, S.; Topcuoglu, N.; Kulekci, G. Effect of two different polishing systems on fluoride release, surface roughness and bacterial adhesion of newly developed restorative materials. Journal of Esthetic and Restorative Dentistry 2017, 29, 424-434, https://doi.org/10.1111/jerd.12313.

36. Karda, B.; Jindal, R.; Mahajan, S.; Sandhu, S.; Sharma, S.; Kaur, R. To analyse the erosive potential of commercially available drinks on dental enamel and various tooth coloured restorative materials-an in-vitro study. Journal of clinical and diagnostic research: JCDR 2016, 10, ZC117, https://doi.org/10.7860/jcdr/2016/16956.7841.

37. Topaloglu-Ak, A.; Çayırgan, D.; Uslu, M. Evaluation of Surface Roughness of Composite, Compomer and Carbomer After Curing Through Mylar Strip and Glycerin: A Comparative Study. Journal of Advanced Oral Research 2019, 11, 12-15, https://doi.org/10.1177\%2F2320206819886141.

38. Tavangar, M.; Bagheri, R.; Kwon, T.-Y.; Mese, A.; Manton, D.J. Influence of beverages and surface roughness on the color change of resin composites. J. Investig. Clin. Dent. 2018, 9, e12333, https://doi.org/10.1111/jicd.12333.

39. Valinoti, A.C.; Neves, B.G.; Silva, E.M.d.; Maia, L.C. Surface degradation of composite resins by acidic medicines and pH-cycling. Journal of Applied Oral Science 2008, 16, 257-265, https://doi.org/10.1590/s1678-77572008000400006.

40. Elwardani, G.; Sharaf, A. A.; Mahmoud, A. Evaluation of colour change and surface roughness of two resinbased composites when exposed to beverages commonly used by children: an in-vitro study. Eur. Arch. Paediatr. Dent. 2019, 20(3), 267-276, https://doi.org/10.1007/s40368-018-0393-1.

41. Tanweer, N.; Jouhar, R.; Ahmed, M.A. Influence of ultrasonic excitation on microhardness of glass ionomer cement. Technol. Health Care 2020, 1-6, https://doi.org/10.3233/THC-191988.

42. Gurdogan Guler, E.B.; Bayrak, G.D.; Unsal, M.; Selvi Kuvvetli, S. Effect of pediatric multivitamin syrups and effervescent tablets on the surface microhardness and roughness of restorative materials: An in vitro study. Journal of Dental Sciences 2021, 16, 311-317, https://doi.org/10.1016/j.jds.2020.03.017.

43. Bociong, K.; Szczesio, A.; Sokolowski, K.; Domarecka, M.; Sokolowski, J.; Krasowski, M.; LukomskaSzymanska, M. The Influence of Water Sorption of Dental Light-Cured Composites on Shrinkage Stress. Materials 2017, 10, https://doi.org/10.3390/ma10101142.

44. Tantanuch, S.; Kukiattrakoon, B.; Peerasukprasert, T.; Chanmanee, N.; Chaisomboonphun, P.; Rodklai, A. Surface roughness and erosion of nanohybrid and nanofilled resin composites after immersion in red and white wine. Journal of conservative dentistry: JCD 2016, 19, 51, https://doi.org/10.4103/0972-0707.173199.

45. Gönülol, N.; Tunç, E.Ş.; Özer, S.; Yıldızlı, K. Evaluation of Water Sorption-solubility and Surface Roughness of Different Bulk Fill Composite Resins. Meandros Medical and Dental Journal 2019, 20, 28, https://doi.org/10.4274/meandros.galenos.2018.86548.

46. Haugen, H.J.; Marovic, D.; Par, M.; Khai Le Thieu, M.; Reseland, J.E.; Johnsen, G.F. Bulk Fill Composites Have Similar Performance to Conventional Dental Composites. Int. J. Mol. Sci. 2020, 21, https://doi.org/10.3390/ijms21145136. 